\title{
Contributors to this issue
}

Alan Firth is Senior Lecturer in the School of Education, Communication and Language Sciences, Newcastle University, UK. His research interests include Conversation Analysis, second language acquisition, English as a lingua franca, and talk and social interaction on telephone helplines and in mediation. Publications include the edited collections The Discourse of Negotiation: Studies of Language in the Workplace (1995, Pergamon Press) and Calling for Help: Language and Social Interaction in Telephone Helplines (2005, Benjamins - with Carolyn Baker and Michael Emmison). His work (with Johannes Wagner) on the reconceptualization of SLA resulted in two 'special issues' of Modern Language Journal (1997 and 2007). He has also published in World Englishes, Journal of Pragmatics, International Journal of Sociology, International Journal of Applied Linguistics, Discourse and Society and American Journal of Sociology, among others.

Juliane House is Professor Emerita of Applied Linguistics at the University of Hamburg and a senior member of the German Science Foundation's Research Centre on Multilingualism, where she directs two projects on multilingual communication. Her research interests include translation, contrastive pragmatics, discourse analysis, politeness theory, English as a lingua franca and intercultural communication.

Anna Mauranen is Professor of English at the University of Helsinki. Her current research interests are English as a lingua franca and modeling spoken language. She has recently compiled a corpus of English as a lingua franca (ELFA) with her research team. Her publications focus on corpus linguistics, speech corpora, translation studies, contrastive rhetoric, and academic discourses. Her major publications include Linear Unit Grammar (co-authored with Sinclair, 2006), Translation Universals-Do They Exist (co-ed. with Kujamäki, 2004), Academic Writing. Intercultural and Textual Issues (co-ed. with Ventola, 1996), Cultural Differences in Academic Rhetoric (1993). She is currently running a corpus-based research project on spoken English as a lingua franca (the ELFA project). 
Lucy Pickering is an Associate Professor in the Department of Applied Linguistics and ESL at Georgia State University, USA. She received her $\mathrm{Ph} . \mathrm{D}$. from the University of Florida in 1999. Her research interests include the applications of speech analysis to discourse analysis, the crosslinguistic transfer of prosodic features and the role of intonational cues in ELF interaction.

Barbara Seidlhofer is Professor of English and Applied Linguistics at the University of Vienna. Her teaching and research focus on corpus linguistics, sociolinguistics, discourse analysis and pragmatics, in particular in their application to language teacher education. She is the founding director of VOICE, the Vienna-Oxford International Corpus of English, and within the EU-project DYLAN (Language dynamics and management of diversity) she is conducting research into the role of English as a Lingua Franca within European multilingualism. 